\title{
FORENSIC ASPECT OF THE DEATH OF KING SEETHAWAKA RAJASINGHE
}

\section{Mendis NDNA ${ }^{1} \&$ Susantha RARP2}

DOI :

http://doi.org/10.4038/sljfmsl. v11i2.7831

Corresponding Author Mendis NDNA

1 Department of Forensic

Medicine \& Toxicology, Faculty of Medicine, Colombo, Sri Lanka

asela@fortox.cmb.ac.lk

https://orcid.org/00000002-4690-9493

2 Nugegoda Ayurvedic Medical Clinic, Sri Lanka

Key Words

cyanide; good faith; intentional poisoning

Article History

Received: 28.02.2020

Received in revised form: 28.06.2020

Accepted: 07.08.2020

Available online: 21.12.2020

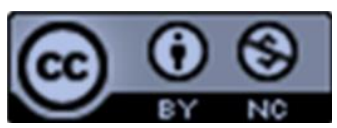

This article is licensed under the terms of the Creative Commons Attribution-Non Commercial 4.0 International License.

e-ISSN : 2465-6089

\begin{abstract}
Seethawaka kingdom existed for a relatively short period of 72 years, 1521-1593 AD. Mayadunne was the first king of Seethawaka and King Rajasinghe succeeded him in 1581. His sudden demise in 1592 is shrouded in mystery and speculations with some considering it to be a result of intentional poisoning. In this research, we investigate the information with regard to intentional harm, circumstances and cause of death.

Many primary sources of information including ola leaves dating back to the late 16th century were reviewed while many other secondary sources were also referred.
\end{abstract}

According to many sources King Rajasinghe sustained a bamboo thorn prick at Pethangoda on his return after a losing battle with King Vimaladharmasuriya I. Many historical accounts and a particular ola leaf letter indicate that a poisonous substance was applied on the king's wound. Recently a few researchers have put forward a theory that the king died of tetanus.

However, it is our view that tetanus is an unlikely condition in this situation. Presence of cyanide in the bamboo stem could have been the lethal substance.
It is also noted that constituents of the wound dressing are known to possess antimicrobial, antiseptic and many other medicinal properties.

The recent discovery of potent antibiotic in horse dung raises a question as to whether physicians in that era knew about the presence of such antimicrobial substance.

In conclusion it is our view that the king probably died of cyanide poisoning and alleged poisonous substances in fact may have been used as treatment in good faith.

\section{INTRODUCTION}

The Seethawaka kingdom existed for a relatively short period of 72 years (1521-1593 AD). The first king of Seethawaka was Mayadunne and in 1581 Prince Seethawaka Rajasinghe succeeded him. According to historians King Rajasinghe first took command of the Seethawaka forces at the age of 11 years. He fought many battles with Portuguese invaders during this period including the famous battle of Mulleriyawa until his untimely death in 1593. However, history reveals that his last battle was with King Vimaladharmasuriya I which he lost. 
It is said that on his return after losing the battle with King Vimaladharmasuriya, at Pethangoda garden a bamboo thorn pierced his sole and he succumbed to its complications within a few days. ${ }^{1,2}$ However, there are different speculations with regard to his death and one famous speculation is that the physician who treated him performed black magic and applied a wound dressing with contaminated substances.

The objective of this paper is to critically review facts regarding King Seethawaka Rajasinghe's death from a forensic viewpoint.

\section{MATERIALS AND METHODS}

Research on documentary evidence available on the said incident was carried out. In this regard Prof. Risiman Amarasinghe's research publication titled 'The Rise and Decline of the Kingdom of Sithawaka' was a valuable document.

Four primary documents were referred in reviewing facts regarding the king's death.

Following primary documents - ola leaves were referred.

i. King Seethawaka Rajasinghe's Birth
ii. Socument
iii. Maniayngama ola leaf
iv. Letter written by Shailendrasinghe the
physician

Many other books and documents written by both local as well as international authors were referred to obtain more facts related to the death of the king.

\section{CASE}

Most common story about King Rajasinghe's death is that a bamboo thorn pierced his sole at Pethangoda garden. According to many sources it is said that 'Dodampe Ganithaya' who treated the king, purposefully applied a dressing of contaminated material including cow-dung, horse-dung and athwagapul. Many believe that the king died of tetanus due to this act. ${ }^{3,4}$

Ellawala Medhananda thero in his article titled 'Historical and Archeological facts of Seethawaka era' states a different view about the death of the king. He refers to an unpublished document which is in his possession which says that King Seethawaka Rajasinghe was assaulted by the followers of prince Rajasuriya.

According to this article, a forceful blow was dealt to the leg for which Dodampe Ganithaya used his black magic and poisonous dressing to kill the king. ${ }^{5}$

Literature review shows that there are three possible explanations or speculations regarding king Rajasinghe's death. Apart from the above mentioned two methods there is another possible explanation given by some that he died following a snake bite. ${ }^{6}$ There are many other sources which indicate different descriptions with regard to the time and place of death of King Seethawaka Rajasinghe., ${ }^{7,8}$

There are various documentary sources describing the survival period of the king following the injury but none provide an exact period of time..$^{8,9,10,11}$ However, according to the ola leaf letter written by Shailendrasighe, the king had died at the '20th jama' which is approximately 80 hours (4th day) after the injury. ${ }^{12}$

Prince Rajasuriya was said to have had an affair with the daughter of Dodampe Ganithaya. According to further information King Seethawaka Rajasinghe has taken this lady forcefully while she was bathing at a place now known as 'Bisowela' and kept her as his 'queen' until her death. However, Amarasinghe in his thesis in 1998 raises doubts as to whether this Rajasuriya was a person other than prince Rajasuriya, King Seethawaka Rajasinghe's grandson. ${ }^{6}$ 
Other sources indicate that there were many people including persons in the hierarchy, such as Buddhist monks who were contemplating on ousting the king. In fact, it was some prominent Buddhist monks including Devanagala Rathanalankara thero and Gampola Rajaguru Dharmakeerthi thero who with some others in the hierarchy planned to oust Seethawaka Rajasinghe and make Konappu Bandara the king of Kandy. ${ }^{10,13}$

\section{Facts}

It is important to know some facts about the constituents of the dressing applied by 'Dodampe ganithaya' and also about the plant called kat una, Tetanus etc.

\section{Constituents of the dressing applied}

\section{Athwagapul:}

Athwagapul is also known as gajathippili and gajapeepal. ${ }^{14}$ This is a plant mainly found in India and also found along sub-Himalayan tract, Bengal, Orissa etc. The botanical name of this plant is Scindapsus officinalis which is said to possess many medicinal properties. It is a medicinal plant used in traditional Indian medicine. It is known to have antioxidant, antiinflammatory, analgesic, anti-microbial and anti-viral properties. ${ }^{15,16}$

\section{Cow dung:}

According to Indian Ayurvedic medicine cow dung is an efficacious disinfectant and often used as fuel in lieu of firewood in India. Cow dung is also considered as an antiseptic. Not only is it free of bacteria but is also effective in killing it. Dried dung is odourless and produces slow even heat. ${ }^{17}$

\section{Horse dung:}

In contrast to cow dung this is known to contain several types of bacteria, fungi etc. However, in 2014 European scientists have discovered a very potent protein called copsin in horse dung which is considered to be resistant to heat, acid and other enzymes. It is also known to have a wide range of anti-bacterial activity which does not develop resistance easily. ${ }^{18}$

\section{Katu una (Bambusa arundinacea):}

It is a medicinal plant used in traditional Indian medicine known to contain chemicals like hydrogen cyanide, benzoic acid etc. in its shoots. There are many other chemical derivatives in this plant, many of which after extraction are used in various illnesses and treatment methods. ${ }^{19}$

\section{Copsin:}

This is an antimicrobial peptide produced by a fungus called Coprinopsis cinerea and a natural substrate for this is dung of herbivores, especially of horses. This peptide has a wide range of anti-bacterial properties and also known to be heat resistant. ${ }^{20,21}$

\section{Tetanus:}

The muscular rigidity and spasms of tetanus are caused by tetanus toxin (tetanospasmin), which is produced by Clostridium tetani, an anaerobic bacillus, whose spores survive in soil and cause infection by contaminating wounds.

According to World Health Organization, the incubation period of tetanus is 3-21 days. ${ }^{26}$ In general, the further the injury site is from the central nervous system, the longer is the incubation period. Shorter incubation periods are associated with a higher chance of death. In neonatal tetanus, symptoms usually appear from 4 to 14 days after birth, averaging about 7 days. ${ }^{27}$

Tetanus is a clinical diagnosis. Mere presence of the tetanus bacteria in the body or in the wound does not result in tetanus. According to research the tetanus bacteria is recovered in only $30 \%$ of cases. Even way back in 1920 s it is recorded that though $20 \%$ of war wounds were contaminated with tetanus bacteria none of them showed any symptoms and signs of tetanus. ${ }^{22}$

Tetanus has four modes of clinical presentation: local, cephalic, generalized and neonatal. However local and cephalic tetanus is somewhat rare in occurrence than generalized tetanus. 
A study in which the proportion dying of tetanus in relationship to probable entry site of the bacteria shows that the lowest death rate is associated with the entry site being the foot of the victim. ${ }^{23}$

\section{DISCUSSION}

The facts regarding this case will analyzed under following topics;

1. Were there people who wanted to oust the king?

2. Is intentional poisoning possible?

3. If it was done how effective is that method in 'killing' the king?

4. Is it possible that Rajasinghe died of tetanus?

5. Are there any other explanation for these events?

According to Amarasinghe there are many sources to indicate that in fact there was a movement to oust King Rajasinghe. In the context of practices that existed during this period 'ousting a king' is almost synonymous with 'killing of the king'.

History reveals that the Portuguese, who were confined to Colombo fort due to the efforts of Rajasinghe harboured a grudge against Rajasinghe. One historical source even indicates an unsuccessfully attempted by the Portuguese to poison him on an earlier occasion. ${ }^{8}$ In the Kandyan kingdom also there were many waiting to oust Rajasinghe especially people like Konappu Bandara who was later crowned as Vimaladharmasuriya $\mathrm{I}$ and his allies etc. Consequently, it may be concluded that there were many who were looking for an opportunity to kill the king.

Under these circumstances it maybe speculated that any of these people would take the first opportunity to kill the king, especially when he is injured and immobile. Poisoning would be an ideal method to kill someone as it would not leave any tell-tale evidence of any interference, outwardly. Considering the events which occurred after the king was injured would also seem to be very conducive to killing of the king.
Many historical sources say that the wound was applied with poisonous substance by Dodampe Ganithaya. ${ }^{6,13}$ Historians usually give more weightage for a fact when similar description is given in multiple sources. This is especially true if any of these documents have been written during the same period or era. Presence of circumstantial evidence on an event does further increases the significance of an event.

In this particular incident as many sources state the application of poisonous substance (visa bandaweema) and letter implicating a particular person - Don Peduru applying this on the king's wound under the influence of certain other people, almost confirms the intention to kill the king. ${ }^{6,10,12}$ However, most of the sources implicate that this was done by Dodampe Ganithaya who was brought to treat the king. But contradicting evidence in Shailendrasinghe's letter implicates another person. This creates doubt as to the identity of the perpetrator. There is also a possibility of both these persons being one and the same. There is no definitive description about 'Don Peduru' anywhere else in other sources. This raises the issue of determining culpability of intentional poisoning on a particular person.

Veerasingam in his article published in 2002 interpret the signs and symptoms demonstrated by King Rajasinghe as being due to tetanus. ${ }^{3}$ He discusses the symptom and signs in its chronological appearance and shows how it corresponds to tetanus. Gunathilake in his article in 2007 agrees with Veerasingam and describes the events and confirms the symptoms and signs to be of tetanus. ${ }^{3,6}$ In an article written to Sunday Lakbima, Dannister Perera analyzing the facts stated by Gunathilake agrees with him although he has raised some concerns about the time Shailendrasinghe's letter was written.

One important aspect that needs to be considered is the exact method of causation of injury to King Rajasinghe. This aspect has been analyzed by Amarasinghe in his thesis in $1998 .{ }^{6}$ 
According to him the most likely method of injury is accidental prick with a bamboo thorn. The speculation of snake bite has to be discarded since there are no reports of such an incident in the literature and according to Amarasinghe it is a folklore existing in the area around Pethangoda. The second speculation of assault to the sole or leg of the king by his enemies also seems to be very unlikely. ${ }^{6}$ Anyone who wanted to harm or kill the king would not have considered assaulting him on the leg as it is very unlikely to result in severe injury or death. However, there is one important point mentioned by Dannister Perera in his article, that is there are 107 fatal points in the body ('marmasthana') according to Ayurveda and one of these is said to be in the anterior part of the sole which is named as 'thalahrudaya'. ${ }^{26}$ Mandarampura Puwatha in its contents mentions that king Rajasinghe was wearing shoes ('Miriwedi) at the time of injury. ${ }^{27}$ In this context it is very unlikely or even impossible for someone to inflict a deadly blow to the sole involving the 'marmasthanaya' called 'thalahrudaya'. Therefore, it can be safely concluded that intentional trauma to the foot/leg of the king is unlikely.

According to another historical document King Rajasinghe fell from the horse in to a pool of mud at Pethangoda where a bamboo thorn pricked his right sole. ${ }^{10}$ Analysis of this information indicates that infliction of trauma to the foot of the king is an accident.

Many sources indicate intentional poisoning of the wound. In a forensic point of view if someone is contemplating to kill another especially a person higher in the hierarchy, he or she would use a method that is sure to kill the victim. Applying a dressing with contaminated material with the expectation that it would cause tetanus is unlikely. In the past when someone becomes the king by killing his predecessor it is usually never questioned. Therefore, killing the wounded king with even an obvious method is not that uncommon.

According to Veerasingam, signs and symptoms mentioned in the ola leaf letter written by
Shailendrasinghe corresponds to those of tetanus. He gives the signs and symptoms developed by the king in a table with the corresponding timing of appearance. ${ }^{3}$ However some symptoms are misinterpreted according to our view. For example, the term 'Wakkutuweema' mentioned in Shilendrasinghe's letter has been considered as opisthotonos. However according to Ayurveda wakkutuweema is flexion of the body and therefore cannot be considered as opisthotonos.

In accordance with the information obtain from various sources King Rajasinghe has died on the fourth day after thorn prick. ${ }^{6}$ according to Shilendrasinghe king has developed symptoms at the beginning of $8^{\text {th }}$ Jama (32 Hours), which means on the $2^{\text {nd }}$ day. Since the incubation period of tetanus is 3-21 days and the injury being in the sole makes it unlikely to be tetanus. Consideration of these facts indicate that the occurrence of tetanus in this situation is doubtful.

Next, for consideration are the effects of thorn prick injury. 'Katu una' is a plant indigenous to India and a few countries in the Indian subcontinent bearing the botanical name Bambusa arundinacea. It contains a wide range of chemical substances and importantly hydrogen cyanide $(\mathrm{HCN})$ in the stem. $^{28}$ According to an analysis done in India young shoots contain $0.03 \% \mathrm{HCN}$ and ingestion of eight grams of raw shoots or slightly more improperly cooked shoots can cause death. ${ }^{29}$ Young shoot emerges from the ground which is of a conical shape. As it emerges from the ground the end of it could be pointed enough to cause injury especially if a person falls on to it.

$\mathrm{HCN}$ is a potent cytotoxic which could cause rapid symptoms and death depending on the amount of poison entering the body. HCN poisoning is known to cause symptoms and signs like headache, tightening sensation of the throat, vomiting to shortness of breath, seizures confusion etc. 
What other evidence is there to suggest $\mathrm{HCN}$ poisoning rather than occurrence of tetanus in this case? Various sources of literature indicate that the King died on the fourth day after the thorn prick. ${ }^{12,13}$ This makes it unlikely to be tetanus as the usual incubation period of tetanus is 3-21 days.

Considering the constituents of the dressing applied to the wound athwagapul which is also known as gaja thippili in Ayurvedic medicine is a medicinal plant. ${ }^{14,15,16}$

Next, we like to analyze the implications of the dressing applied to the wound. According to Shailendrasinghe's letter it contained of horsedung, cow-dung and athwagapul. Athwagapul which is also known as gaja thippili in Ayurvedic medicine is a medicinal plant. ${ }^{14,15,16}$ It is also known to cause dehydrating effect on tissues. ${ }^{15,16}$ Therefore, it is very likely that it had been used for its medicinal properties to relieve pain, inflammation etc. Cow-dung according to Indian Ayurvedic practice is a sterile substance. In addition, they consider it to possess antiseptic effects as well. ${ }^{17}$ In contrast to cow-dung, horse-dung is known to contain a wide range of bacteria and fungi. Could it be the substance which caused lethal complications? Scientists have discovered a fungus called Coprinopsis cinerea that grows in horse dung which produces a protein called 'copsin' which is known to have very potent broad spectrum anti-microbial properties. Shailendrasinghe in his letter about application of this dressing says 'thalathelin kakara' is heating and stirring till most of the water evaporates while Veerasingam suggests that this was done to kill bacteria other than the tetanus bacteria which is supposed to be heat resistant. ${ }^{13}$ However, this is not a very practical way of killing other organisms leaving only tetanus spores. On the other hand, it could have been done to kill all other organisms and keep the copsin remaining in the substance so that it could exert its antibacterial properties more effectively.

\section{CONCLUSIONS}

To use a method expected to cause tetanus and death is an unlikely to be used to kill a person. It is far easier to use a known potent poison for this purpose. Furthermore, mere introduction of spore bearing tetanus bacteria will not always result in tetanus.

Therefore, we conclude that use of contaminated material to dress the wound to cause tetanus is an unlikely method if the intention was to kill King Seethawaka Rajasinghe.

Furthermore, considering the rapid onset of symptoms and death make tetanus unlikely. In our opinion, death would have resulted due to hydrogen cyanide poisoning by bamboo thorn prick. It is very likely that whoever dressed the wound did it in good faith. Considering this evidence, we conclude that the possible circumstance of death would be accidental and not homicidal.

We do not intend to discard the possibility of tetanus as a cause of death in this case but analysis of the facts and evidence makes hydrogen cyanide ( $\mathrm{HCN})$ poisoning more possible than tetanus.

However, since this is an analysis historical data and facts stated by different individuals both medical and non-medical it is almost impossible to arrive at a definite and accurate conclusion about circumstances of death or the cause of death. 


\section{ETHICAL ISSUES}

None

\section{CONFLICTS OF INTEREST}

There are no conflicts of interest

\section{ACKNOWLEDGEMENTS}

Professor Risimon Amarasinghe for his valuable contribution with regard to the history of Seethawaka kingdom.

\section{AUTHOR CONTRIBUTIONS}

NDNAM: Perusal of documents and writing the article; RARPS: Perusal of documents, providing facts on Ayurvedic medicine and editing the article.

\section{REFERENCES}

1. De Queyroz F. The Temporal and Spiritual Conquest of Ceylon Vol 2. Perera SG, Richards AC, translator. Colombo; 1930

2. Couto D. History of Ceylon (HCC). JCBRAS, 1908;20(60).

3. Veerasingam P. Analysis of the reported symptoms that preceded the death of King Rajasinghe of Sithawake (1592 AD). Ceylon Medical Journal. 2011 Aug 25;47(2): 65-67.

4. Sunday Lakbima. 2007 Mar 04.

5. Medhananda E. Historical and archaeological fact of Seethawaka era. In: Ariyawansha W. (eds.) Seethawaka Pura Yugaya. Maradana: Godage International Publishers; 1991. p27-30.

6. Amarasinghe $\mathrm{R}$. The rise and decline of the kingdom of Sithawaka. Maharagama: Tharanjee Printers; 1998.

7. Baldaeus P. A true and exact description of the great island of Ceylon. Brohier $\mathrm{P}$, translator. Kohuwala: Thisara Prakashakayo; 1960

8. Pieris PE. Ceylon - the Portuguese era (Vol. 1). Kohuwala: Thisara Parkashakayo; 1992.

9. Alakeshwara Yuddhaya. pp42.
10. Maniyangama ola leaf

11. Rajavaliya. pp232

12. Shailendrasinghe ola leaf

13. Seethawaka Rajasinghe Rajja Kale

14. Department of Ayurvedha. Ayurvedha Oushada Sangrahaya, 1st step, 2nd part. pp73-74.

15. Kaushik D, Kaushik P, Tuteja R, Choudhary B. Scindapsus officinalis: a comprehensive review. International Journal of Pharmaceutical Erudition. 2012;2(2): 18-27.

16. Shrivastava N, Vikram P, Tahlani P. Scindapsus officinalis fruit a phytochemical and pharmacological review. World Journal of Pharmacy and Pharmaceutical Sciences. 2014;3(2): 2626-2636.

17. Trueayurveda. Cow dung uses and used for centuries. Available from: https://trueayurveda.wordpress.com/2014/04/ 09/cow-dung-uses-and-used-for-centuries/ [Accessed 9th April 2017]

18. Thanh Nien News. Horse dung has scientists on scent of antibiotic success. Available from: http://www.thanhniennews.com/health/horsedung-has-scientists-on-scent-of-antibioticsuccess-39889.html [Accessed 9th April 2017]

19. Rathaur AK. Bambusa arundinacea (vanshlochan): an overview. International Journal of Research in Pharmacology and Pharmacotherapeutics. 2013;2(1):248-55.

20. Essig A, Hofmann D, Münch D, et al. Copsin, a novel peptide-based fungal antibiotic interfering with the peptidoglycan synthesis. Journal of Biological Chemistry. $2014 \quad$ Dec 12;289(50):34953-64.

doi:10.1074/jbc.M114.599878.

21. Reuters. Horse dung has scientists on scent of antibiotic success. Available from: https://www.reuters.com/article/usswitzerland-horse-dung-mushrooms/horsedung-hasscientists-on-scent-of-antibioticsuccess-idUSKBNOMC12920150316 [Accessed 9th April 2017] 
22. Mihalovic D. Why you never need a tetanus vaccine, regardless of your age or location. Available from: https://preventdisease. com/news/13/050713_Why-You-Never-NeedA-Tetanus-Vaccine-Regardless-of-Your-Age-orLocation.shtml?no_redirect= true [Accessed 9th April 2017]

23. Thwaites $\mathrm{CL}$, Yen LM, Glover C, et al. Predicting the clinical outcome of tetanus: the tetanus severity score. Tropical Medicine \& International Health. 2006 Mar;11(3):279-87. doi:https://doi.org/ 10.1111/j.13653156.2006.01562.x

24. Gururaja D, Soumyashri, Prabhu N. A critical review on marma manifestation and manipulation in gridhrasi. International journal of Ayurveda research. 2019;3(3).
25. Mandarampura puwatha. Poem 85. pp23

26. World Health Organization. Tetanus. Available from: https://www.who.int/news-room/factsheets/detail/tetanus

27. Centers for Disease Control and Prevention. Tetanus. Available from: https://www.cdc. gov/ tetanus/clinicians.html

28. Rathod JD, Pathak NL, Patel RG, Jivani NP, Bhatt NM. Phytopharmacological properties of Bambusa arundinacea as a potential medicinal tree: an overview. Journal of Applied Pharmaceutical Science. 2011 Dec;1(10):27-31.

29. C.S.I.R. (Council of Scientific and Industrial Research). 1948-1976. The wealth of India. 11 vols. New Delhi. 